Л. В. Радецька, Н. В. Пасєчко, Н. І. Ярема, А. О. Боб, І. В. Смачило, І. П. Савченко, М. Є. Гаврилюк, Л. В. Наумова, А. І. Хоміцька, Т. І. Крицький,

ДВНЗ “Тернопільський державний медичний університет

імені І. Я. Горбачевського МОЗ України”

\title{
ДОСВІД ОРГАНІЗАЦІЇ САМОСТІЙНОЇ РОБОТИ СТУДЕНТІВ IV КУРСУ У ПРОЦЕСІ ВИВЧЕННЯ ВНУТРІШНЬОЇ МЕДИЦИНИ
}

\author{
L. V. Radetska, N. V. Pasyechko, N. I. Yarema, A. O. Bob, I. V. Smachylo, \\ I. P. Savchenko, M. E. Gavrylyuk, L. V. Naumova, A. I. Chomicka, T. I. Krytskyy, \\ I. Horbachevsky Ternopil State Medical University

\section{ORGANIZATION OF INDEPENDENT WORK OF THE IV COURSE STUDENTS DURING STUDYING INTERNAL MEDICINE}

Z. P. Mandziy

\begin{abstract}
Мета роботи - вдосконалення організації самостійної роботи студентів медичного факультету з використанням інтерактивних методів педагогіки.

Основна частина. У статті, з метою інтеграції навчального процесу до Європейського простору, висвітлено питання організації самостійної роботи студентів в освітньому процесі з урахуванням можливостей сучасних інформаційних технологій навчання. Проаналізовано власний досвід проведення практичних занять для студентів IV курсу медичного факультету на основі наявних у наукових публікаціях даних про результати впровадження даної форми навчання у вищих медичних навчальних закладах України.

У рамках традиційної парадигми навчання наявні добре відпрацьовані структури забезпечення викладацької діяльності, що зводяться в основному до читання лекцій і проведення семінарських та практичних занять у лекційно-дискусійному форматі. Дотримуючись точки зору про те, що самостійна робота - це вид навчально-пізнавальної діяльності студента 3 освоєння професійної освітньої програми за партнерської участі викладача у її плануванні й оцінці досягнення конкретного результату, слід визнати, що можна говорити лише про певний ступінь самостійності при виконанні різних типів самостійних робіт.

Основне завдання викладача зводиться не до викладу готових знань, а до організації навчання. Головна мета викладача в такій моделі навчання - навчити студента “як вчитися”.

Висновок. Вміле педагогічне управління, використання різних індивідуально-орієнтованих форм навчання дозволяє досягти більшої самостійності і ставить студента у такі умови, в яких у нього з'являються освітні потреби і, як наслідок, намагання оволодіти професійними знаннями та вміннями, а в результаті у майбутньому стати професіоналом.
\end{abstract}

Ключові слова: методика організації самостійної роботи студентів; практичні заняття; самостійна робота аудиторна та позааудиторна; якість навчання.

The aim of the work - to improve the organization of independent work of students of the medical faculty with the use of interactive methods of pedagogy.

The main body. The article consists of the problem of independent students work organization in educational process taking into consideration modern technologies of studying. It is made in the aim of integration to European space. The own experience of practical lessons of the IV course medical students is also analyzed. It was performed due to the presence of scientific publications about results of implementation this form of education in universities of Ukraine.

Within the framework of the traditional paradigm of training, there are well-developed structures for providing teaching activities, which are reduced mainly to lectures and seminars and practical classes in the lecture-discussion format. Adhering to the view that independent work is a kind of educational and cognitive activity of the student on the development of a professional educational program for the participation of the teacher in its planning and evaluation of the achievement of a particular result, it should be recognized that we can speak only of a certain degree of autonomy in the implementation of different types independent work.

The main task of the teacher is not to present the finished knowledge, but to organize the training. The main purpose of the teacher in this model of training is to teach the student how to study.

Conclusion. Intelligent pedagogical management, the use of various individual-oriented forms of studying allows achieving greater independence and puts the student in conditions in which he develops educational needs and, as a result, an attempt to gain professional knowledge and skills, resulting to become a professional in the future.

Key words: methods of independent work; practical employments; methodical developments; quality of studies.

( ) Л. В. Радецька, Н. В. Пасєчко, Н. І. Ярема та ін. 
Вступ. Підготовка висококваліфікованих кадрів, здатних вирішувати професійні завдання будь-якої складності, є однією з умов впроваджуваного зараз в Україні реформування системи вищої освіти і охорони здоров'я. У зв’язку з цим різко зростає роль самостійної роботи студентів, яка стає головним резервом підвищення якості підготовки майбутніх фахівців [1, 2].

Мета роботи - визначення основних напрямів покращення та вдосконалення навчального процесу студентів IV курсу з внутрішньої медицини відповідно до вимог Європейської системи знань 3 метою підготовки та виховання майбутніх фахівців міжнародного рівня.

Основна частина. 3 урахуванням провідної ролі самостійної роботи студентів під час засвоєння знань та умінь 3 дисципліни “Внутрішня медицина” нами опрацьовані робочі програми і методичні вказівки до практичних занять, які розроблені на кафедрі, що включають самостійну роботу студентів, тестові завдання з різних розділів дисципліни за допомогою вибіркового методу аналітичного дослідження.

Освітній процес на кафедрі внутрішньої медицини № 1 базується на положеннях Закону України “Про вищу освіту” і здійснюється згідно з типовою навчальною програмою з дисципліни “Внутрішня медицина” (2013). У рамках традиційної парадигми навчання наявні добре відпрацьовані структури забезпечення викладацької діяльності, що зводяться в основному до читання лекцій і проведення семінарських та практичних занять у лекційнодискусійному форматі. Дотримуючись точки зору про те, що самостійна робота - це вид навчальнопізнавальної діяльності студента 3 освоєння професійної освітньої програми за партнерської участі викладача у її плануванні й оцінці досягнення конкретного результату, слід визнати, що можна говорити лише про певний ступінь самостійності при виконанні різних типів самостійних робіт [2]. Процес формування самостійності передбачає поступову передачу функцій управління навчальною діяльністю від викладача до студента, при цьому змінюється позиція студента та приходить усвідомлення того, що навчитися можна тільки самому. Основне завдання викладача зводиться не до викладу готових знань, а до організації навчання. Головна мета викладача в такій моделі навчання навчити студента “як вчитися”. У його основі лежить використання спеціальних технологій, які допомагають організувати процес вільної комунікації, обміну думками, і підводить студента до прийняття рішення за рахунок реалізації внутрішніх можливостей.

Робочою програмою з внутрішньої медицини для студентів IV курсу медичного факультету передбачено 240 годин, з них 46 годин складають лекції і 114 годин - практичні (аудиторні) заняття (1 заняття - 6 академічних годин, всього 19 занять). Позааудиторна самостійна робота становить 80 годин. Самостійна робота студента є основним засобом оволодіння навчальним матеріалом у час, вільний від обов'язкових навчальних занять, і передбачає вивчення тем, що не розглядаються на практичних заняттях, але входять у навчальні програми 3 дисциплін і контролюються під час підсумкових занять, семестрових заліків та іспитів. Навчальний час, відведений для самостійної роботи студента, регламентується робочим навчальним планом. Зміст самостійної роботи визначається навчальною програмою з дисципліни, їі мета - закріплення навичок розумових та мануальних дій (самонавчання). Самостійна робота студента забезпечується системою навчально-методичних засобів, передбачених для вивчення конкретної навчальної дисципліни: підручники, навчальні та методичні посібники, конспекти лекцій, матеріали для підготовки для лекцій, віртуальні навчальні програми, навчальні відеофільми, інтернет-ресурси тощо. Методичні матеріали для самостійної роботи студентів передбачають можливість проведення самоконтролю 3 боку студента та дистанційного контролю у системі Moodle. 3 метою організації методично керованої позааудиторної роботи студентів викладачами кафедри складено методичні рекомендації, у яких обгрунтовано актуальність теми, визначено мету заняття, вказано на ті знання та вміння, якими повинен студент оволодіти самостійно. На заняттях використовуються наочні посібники, схеми, таблиці, малюнки, муляжі, мультимедійні презентації, наводяться приклади з практичної діяльності, проводиться курація хворих у спеціалізованих відділеннях. Студентам рекомендується список обов'язкової та додаткової літератури. Використовуються групові та індивідуальні завдання. Контроль знань здійснюється у вигляді усного опитування, тестових завдань, розв'язання ситуаційних задач, участі у дискусії. Самостійна робота студента над засвоєнням навчального матеріалу з внутрішньої медицини може виконуватись у бібліотеці університету, навчальних лабораторіях, комп’ютерних класах, клініках та у домашніх умовах. 
Аудиторна самостійна робота представлена у таких варіантах, як: виконання завдань зі спостереження і збору матеріалів у процесі практичного заняття (курація хворого, обгрунтування діагнозу, оформлення щоденника); участь у роботі семінару: усна відповідь, доповідь, повідомлення, дискусія; вирішення задач; рольові ігри (Case-Study); підсумковий контроль знань (у т. ч. тести) - письмове виконання.

Ступінь самостійності студентів в усіх зазначених варіантах самостійної роботи різний і залежить від її мети, змісту, форми організації, рівня інтелектуального розвитку й академічної підготовленості студентів, а також педагогічної майстерності викладача.

Рекомендоване співвідношення часу, відведеного на аудиторну і позааудиторну роботу, в усьому світі

\section{Список літератури}

1. Вороненко Ю. В. Ризик виникнення освітньої сингулярності: тенденції та можливі наслідки / Ю. В. Вороненко, О. П. Мінцер // Медична інформатика та інженерія. - 2013. - № 1. - С. 4-11.

2. Хребтій Г. І. Інноваційні технології, направлені на розвиток клінічного мислення у студентів вищих медичних навчальних закладів України / Г. І. Хребтій // Буковинський медичний вісник. - 2015. - Т. 19, № 2. C. 252-255.

\section{References}

1. Voronenko, Yu.V., \& Mintser, O.P. (2013). Ryzyk vynyknennia osvitnoi synhulairnosti: tendentsii ta mozhlyvi naslidky [The risk of the emergence of educational singularity: trends and possible consequences]. Medycna informatyka ta inzheneriia - Medical Informatics and Engineering, 1, 4-11 [in Ukrainian].

2. Khrebtii, H.I. (2015). Innovatsiini tehnolohii, napravleni na rozvytok klinicnoho myslennia u studentiv vyshchykh medycnykh navchalnykh zakladiv Ukrainy [Innovative technologies aimed at the development of clinical thinking among students of higher medical educational institutions of Ukraine]. Bukovynskyi medycnyi visnyk - Bukovyna Medical Journal, 9, 2, 252-255 [in Ukrainian].

3. Kompetentnisnyi pidkhid v osviti: teoretychni zasady i praktyka realizatsii: materialy metodol. seminaru становить 1:3,5. Самостійна робота студентів, передбачена навчальним планом, повинна становити 50-70 \% від загальної кількості годин. Існуючі розрахунки часу на аудиторну і позааудиторну самостійну роботу не враховують конкретних умов і можуть не задовольняти викладачів. Для цього можна організувати експериментальну роботу і протягом навчального року визначити реальну кількість годин, яку витрачають студенти на різні види самостійної роботи.

Висновок. Вміле педагогічне управління, використання різних індивідуально-орієнтованих форм навчання дозволяє досягти більшої самостійності і ставить студента в такі умови, у яких у нього 3' являються освітні потреби і, як наслідок, намагання оволодіти професійними знаннями та вміннями, а в результаті у майбутньому стати професіоналом.

3. Компетентнісний підхід в освіті: теоретичні засади і практика реалізації : матеріали методол. семінару (Київ, 3 квіт. 2014 р.) [редкол.: В. Г. Кремень, В. І. Луговий, О. І. Ляшенко та ін.] ; Нац. акад. пед. наук України. - К. : Ін-т обдарованої дитини НАПН України, 2014. - 370 с.

4. Опар Н. В. Особливості нормативно-правового забезпечення якості вищої освіти в Україні в умовах євроінтеграції / Н. В. Опар. - Режим доступу : httl:// el-zbirn-du.at.ua/2015_1/22.pdf.

(Kyiv, 3 kvit. 2014 r.) [Competency approach in education: theoretical foundations and practice of realization: materials method. Workshop (Kyiv, April 3, 2014)]. Nats. akad. ped. nauk Ukrainy; redkol.: V.H. Kremen, V.I. Luhovyi, O.I. Liashenko ta in. - National acad. ped Sciences of Ukraine; Editorial: V.H Kremen, V.I. Luhovyi, O.I. Liashenko and others. - Kyiv: In-t obdarovanoi dytyny NAPN Ukrainy [in Ukrainian].

4. Opar, N.V. (2015). Osoblyvosti normatyvno-pravovoho zabezpechennia yakosti vyshchoi osvity v Ukraini $v$ umovakh yevrointehratsii [The peculiarities of the normative-legal ensuring of the quality of higher education in Ukraine in the conditions of European integration]. Retrieved from: httl:// el-zbirn-du.at.ua/2015_1/22.pdf. [in Ukrainian]. 